\title{
Acetonitrile degradation under haloalkaline conditions by Natronocella acetinitrilica gen. nov., sp. nov.
}

\begin{abstract}
Correspondence
Dimitry Yu. Sorokin

soroc@inmi.host.ru or

d.y.sorokin@tnw.tudelft.nl
\end{abstract}

Received 7 November 2006

Revised 11 December 2006

Accepted 18 December 2006

\author{
Dimitry Yu. Sorokin, ${ }^{1,2}$ Sander van Pelt, ${ }^{3}$ Tatjana P. Tourova, ${ }^{1}$ \\ Shinichi Takaichi ${ }^{4}$ and Gerard Muyzer ${ }^{2}$
${ }^{1}$ Winogradsky Institute of Microbiology, Russian Academy of Sciences, Prospect 60-let Octyabrya 7/2, 117811 Moscow, Russia

${ }^{2}$ Environmental Biotechnology, Faculty of Applied Sciences, Department of Biotechnology, Delft University of Technology, Delft, The Netherlands

${ }^{3}$ Biocatalysis and Organic Chemistry, Faculty of Applied Sciences, Department of Biotechnology, Delft University of Technology, Delft, The Netherlands

${ }^{4}$ Biological Laboratory, Nippon Medical School, Kosugi, Nakahara, Kawasaki 211-0063, Japan

\section{INTRODUCTION}

Compounds containing a $\mathrm{C} \equiv \mathrm{N}$ group belong to the wide family of nitriles. These are mostly organic molecules of variable complexity with only two inorganic species (cyanide and thiocyanate) included. Most of the nitriles are industrially produced as intermediates and building blocks in organic synthesis and as organic solvents. There are also a few examples of naturally occurring nitriles, such as linamarin and dhurrin, formed by cyanogenic plants from cyanide (Vetter, 2000). In addition, simple aliphatic nitriles, such as isobutyronitrile, can be produced during anaerobic degradation of proteins (Harper \& Gibbs, 1979).

The GenBank/EMBL/DDBJ accession numbers for the 16S rRNA gene sequences of strains ANL 1 and ANL 6-2 ${ }^{\top}$ are EF103127 and EF103128, respectively.
The nitrile bond is chemically very stable and most of the nitriles are hydrophobic and toxic compounds. Therefore, the environmental role of its enzymic degradation is very important. Currently, two different mechanisms, resulting in enzymic conversion of nitriles to corresponding carboxylic acids, are known. The group of nitrile hydratases hydrolyses a wide range of mostly aliphatic and arylaliphatic nitriles to corresponding amides. Organisms possessing nitrile hydratases usually also produce amidases, which finalize the nitrile degradation to corresponding carboxylic acids and ammonium (Kobayashi \& Shimizu, 1998). In case of amidase deficiency, a consortium with an amidase-producing partner can be very efficient in complete nitrile degradation as has recently been shown for acetonitrile degradation in a binary culture of Gram-positive bacteria (Kohyama et al., 2006). Alternatively, the enzyme family of nitrilases directly converts mostly aromatic nitriles into acids and ammonium 
in a single step (Kobayashi \& Shimizu, 2000; Podar et al., 2006). The micro-organisms possessing these enzymes are valuable biocatalysts and can be used either in organic synthesis or in environmental biotechnology (Banerjee et al., 2002; Håkansson et al., 2005; Manolov et al., 2005; Kohyama et al., 2006).

The obvious advantages of enzymic nitrile degradation have stimulated active screening for producers both directly, by a traditional microbiological approach (Layh et al., 1997) and indirectly, using molecular screening of environmental DNA and whole-genome sequences (Vetter, 2000). Currently, many strains, mostly bacterial but also several fungal, are characterized as active producers of nitrilehydrolysing enzymes. The most active group among them, producing extremely active nitrile hydratases and nitrilases, belongs to the genus Rhodococcus (Bunch, 1998; Kobayashi \& Shimizu, 1998). So far, all known nitrile-degrading microorganisms are neutrophilic, i.e. growing optimally at neutral $\mathrm{pH}$ values, and one of them, Bacillus pallidus, is thermophilic (Almatawah et al., 1999).

Until now, there has been no evidence of the possibility of nitrile biodegradation at high $\mathrm{pH} / \mathrm{salt}$ conditions. Microorganisms, mainly prokaryotes, which grow optimally at a $\mathrm{pH}$ above 9 and up to 11 in soda/ $\mathrm{NaCl}$ brines of variable concentrations are called haloalkaliphiles and can be found in such natural habitats as soda lakes and soda solonchak soils. This ability is widely distributed among different phylogenetic lineages of prokaryotes and almost all physiological groups are represented (Jones et al., 1998; Sorokin \& Kuenen, 2005; Zavarzin et al., 1999). There are some data on biodegradation of inorganic nitriles, such as cyanide $\left(\mathrm{N} \equiv \mathrm{C}^{-}\right)$(Luque-Almagro et al., 2005) and thiocyanate $\left(\mathrm{N} \equiv \mathrm{C}-\mathrm{S}^{-}\right)$(Sorokin et al., 2001) at high $\mathrm{pH}$. However, the enzymes involved are different from the nitrile-degrading nitrile hydratase and nitrilase, and organic nitriles cannot be degraded by these bacteria. This prompted us to look at the potential for nitrile degradation in haloalkaliphilic microbial communities. Acetonitrile $\left(\mathrm{CH}_{3}\right.$ $\mathrm{C} \equiv \mathrm{N}$ ) was chosen as a start substrate, because it is the simplest organic nitrile, widely used as solvent and an important environmental pollutant. The results indicate the presence of a specialized group of previously unknown haloalkaliphilic bacteria capable of growing with acetonitrile as sole substrate.

\section{METHODS}

Samples. Three combined sediment samples from Kulunda Steppe (Altai, Russia; 10 subsamples), Wadi Natrun (Egypt; 8 subsamples), north-east Mongolian (6 samples) soda lakes and one sample from soda solonchak soils (Kulunda Steppe, 10 subsamples) were used as the inoculum to enrich for acetonitrile-degrading haloalkaliphiles. The lake properties were described previously (Sorokin \& Kuenen, 2005). The $\mathrm{pH}$ of the water extract from the solonchak samples varied from 9.5 to 10.8 , total alkalinity ranged from 0.05 to $1.2 \mathrm{~mol} \mathrm{~kg}^{-1}$ and total salt content from 3 to $20 \%(\mathrm{w} / \mathrm{w})$. The dominant ions in both habitats were $\mathrm{Na}^{+}, \mathrm{Cl}^{-}, \mathrm{HCO}_{3}^{-} / \mathrm{CO}_{3}^{2-}$ and $\mathrm{SO}_{4}^{2-}$.
Medium composition and enrichment strategy. A mineral medium based on sodium carbonate buffer at $\mathrm{pH} 10$ and $0.6 \mathrm{M}$ total $\mathrm{Na}^{+}$was used for enrichments and pure culture studies $\left(\mathrm{g} \mathrm{l}^{-1}\right): \mathrm{Na}_{2} \mathrm{CO}_{3}, 22 ; \mathrm{NaHCO}_{3}, 8 ; \mathrm{NaCl}, 6 ; \mathrm{K}_{2} \mathrm{HPO}_{4}, 0.5$. The $\mathrm{pH}$ of this medium was stable even after prolonged incubation. After sterilization, the medium was supplemented with $1 \mathrm{ml}$ trace metal solution $1^{-1}$ (Pfennig \& Lippert, 1966), $1 \mathrm{mM} \mathrm{MgSO}$ and $1 \mathrm{mg}$ filtersterilized vitamin $\mathrm{B}_{12} \mathrm{1}^{-1}$. Enrichment cultures were established in $100 \mathrm{ml}$ serum bottles closed with rubber stoppers containing $20 \mathrm{ml}$ medium and $1 \mathrm{ml}$ sediment samples or $1 \mathrm{~g}$ soil. Acetonitrile (Merck) was added to a final concentration of $10 \mathrm{mM}$ from a $5 \mathrm{M}$ filter-sterilized stock solution. The cultures were incubated statically at $28{ }^{\circ} \mathrm{C}$ and were periodically checked for ammonia production. When the ammonia concentration reached $5 \mathrm{mM}$, the culture was transferred into a new medium at $1: 10$ dilution. After four successful $1: 10$ transfers, it was serially diluted up to $10^{-11}$. The culture from a maximal positive dilution was plated onto solid medium, initially containing $20 \mathrm{mM}$ acetonitrile. The plates were incubated in closed jars for 30 days. Separate colonies were placed into liquid medium with acetonitrile in $30 \mathrm{ml}$ serum bottles with $5 \mathrm{ml}$ liquid and closed with rubber septa. Positive cultures were plated again to check for purity.

Growth experiments with pure cultures were performed in $250 \mathrm{ml}$ closed serum bottles with $50 \mathrm{ml}$ liquid on a rotary shaker at 100 r.p.m. and $30^{\circ} \mathrm{C}$. Substrates were used at $10-20 \mathrm{mM}$ concentration. Growth was monitored by optical density and the degradation of nitriles was followed by ammonium production. When compounds other than nitriles were used as substrates, $5 \mathrm{mM} \mathrm{NH}_{4} \mathrm{Cl}$ was added as the $\mathrm{N}$ source. Anaerobic growth with acetonitrile or acetate was studied in $100 \mathrm{ml}$ serum bottles filled with $80 \mathrm{ml}$ medium, containing $10 \mathrm{mM}$ substrate and either $10 \mathrm{mM}$ nitrate or $5 \mathrm{mM}$ nitrite. The cultures were made anoxic by several cycles of evacuation/flushing with argon. Largescale cultivation with acetonitrile was performed in 201 closed bottles with 41 medium. $\mathrm{pH}$ profiling of growth was done according to Sorokin (2005). The salt dependence of growth was investigated in a range of sodium carbonate-based media containing $0.2-4.0 \mathrm{M}$ total $\mathrm{Na}^{+}$at $\mathrm{pH} 10$.

Experiments with washed cells and cell-free extract. To determine the metabolic activity of the pure cultures with various substrates and the influence of $\mathrm{pH}$ and salt concentration on the activity of acetonitrile degradation, cells grown at $\mathrm{pH} 10$ and $0.6 \mathrm{M}$ $\mathrm{Na}^{+}$were harvested, washed and resuspended in $0.5 \mathrm{M}$ sodium bicarbonate, $\mathrm{pH} 8.2$, at a cell density of $20 \mathrm{mg}$ protein $\mathrm{ml}^{-1}$. This concentrated suspension could be kept on ice for at least a week without substantial loss in activity. To obtain a cell-free extract, the same cell suspension was treated by sonication followed by the removal of unbroken cells by centrifugation. Activity tests with washed cells and cell extract were carried out in $2.2 \mathrm{ml}$ Eppendorf tubes with $2 \mathrm{ml}$ reaction mixture. The $\mathrm{pH}$ and salt influence on activity in cell preparations was examined in the same buffers as used in growth experiments, except that potassium phosphate was replaced by $50 \mathrm{mM} \mathrm{KCl}$.

Analytical procedures. Protein concentration was measured by the Lowry method. Ammonium concentration was determined by the phenol-hypochlorite method, according to Weatherburn (1967). Nitrite was analysed qualitatively using the Merckoquant Nitrite Test (Merck) and quantitatively according to Gries-Romijn-van Eck (1966). The concentration of acetonitrile, acetamide and acetic acid in culture supernatant was determined by GC after extraction with dichloromethane $(5: 95)$. The analysis was carried out on a Varian Star 3400 CX system with a Varian Chrompack CP-Wax 52 CB column $(50 \mathrm{~m} \times 0.53 \mathrm{~mm}$, o.d. $=0.70 \mathrm{~mm}$, d.f. $=2.0)$ with a temperature gradient of $50-250{ }^{\circ} \mathrm{C}$. The detection limit of the analysis was around $1 \mathrm{mM}$. Acrylonitrile, acryloamide and acrylic acid were 
detected by HPLC using a Merck Chromolith SpeedROD RP-18e $(50-4.6 \mathrm{~mm})$ with the eluent containing MilliQ water $(98.94 \%$, $\mathrm{v} / \mathrm{v})$, acetonitrile $(1 \%, \mathrm{v} / \mathrm{v})$ and acetic acid $(0.06 \%, \mathrm{v} / \mathrm{v})$. The flow rate was $1 \mathrm{ml} \mathrm{min}^{-1}$ and the column temperature was $21^{\circ} \mathrm{C}$. The compounds were detected using a Shimadzu SPD-6A UV spectrophotometric detector with a wavelength of $230 \mathrm{~nm}$. Pigments were extracted from freeze-dried cells with acetone/methanol $(7: 2, \mathrm{v} / \mathrm{v})$ and analysed by an HPLC system equipped with a $\mu$ Bondapak C18 column $(8 \times 100 \mathrm{~mm}$, RCM-type; Waters $)$ with methanol as the eluent (Takaichi \& Shimada, 1992). The circular dichroism spectrum was measured using a J-820 spectropolarimeter (JASCO) in diethyl ether/2-pentane/ethanol $(5: 5: 2$, by vol.) at room temperature. The relative molecular masses were measured using an FD-MS: M-2500 double-focusing gas chromatograph-mass spectrometer (Hitachi) equipped with a field-desorption apparatus. The ${ }^{1} \mathrm{H}-\mathrm{NMR}$ $(500 \mathrm{MHz})$ spectra in $\mathrm{CDCl}_{3}$ at $24{ }^{\circ} \mathrm{C}$ were measured using the UNITY INOVA-500 system (Varian). Membrane fatty acids were extracted from the freeze-dried cells with methanol/chloroform and analysed by GC-MS as described by Zhilina et al. (1997).

Phase-contrast micrographs were obtained using a Zeiss Axioplan Imaging 2 microscope. For electron microscopy, cells were fixed with glutaraldehyde (final concn $3 \%, \mathrm{v} / \mathrm{v}$ ) and positively contrasted with $1 \%(\mathrm{w} / \mathrm{v})$ uranyl acetate. For thin sectioning, the cells were fixed in $1 \%$ $(\mathrm{w} / \mathrm{v}) \mathrm{OsO}_{4}+0.5 \mathrm{M} \mathrm{NaCl}$ for $3 \mathrm{~h}$ at room temperature, washed and stained overnight with $1 \%(\mathrm{w} / \mathrm{v})$ uranyl acetate, dehydrated in ethanol series and embedded in Epon resin. Thin sections were stained with $1 \%$ $(\mathrm{w} / \mathrm{v})$ lead citrate. The isolation of the DNA and subsequent determination of $\mathrm{G}+\mathrm{C}$ content and DNA-DNA hybridization were performed by the thermal denaturation/reassociation technique (Marmur, 1961; De Ley et al., 1970).

Genomic DNA for phylogenetic analysis was extracted from cells by using the UltraClean Soil DNA Extraction Kit (MolBio Laboratories), following the manufacturer's instructions. 16S rRNA genes were amplified using general bacterial primers. The PCR products were purified from low-melting-point agarose using the Wizard PCRPrep kit (Promega), according to the manufacturer's instructions. Sequencing was performed using the Big Dye Terminator v.3.1 sequencing reaction kit on an ABI 3730 DNA automatic sequencer (Applied Biosystems). The sequences were first compared with those stored in GenBank using the BLAST algorithm and aligned using CLUSTALW. Phylogenetic trees were constructed with four different algorithms using the TREECONW program package (van de Peer \& de Wachter, 1994).

\section{RESULTS}

\section{Enrichment and isolation of pure cultures of acetonitrile-utilizing haloalkaliphiles}

An enrichment from soda soils failed, but in two out of three enrichments from soda lakes (Kulunda Steppe and Mongolia) some ammonia formation was observed after more than a month of incubation. After several $1: 100$ transfers, the growth gradually intensified to a visible turbidity. The culture from the Kulunda lakes was highly aggregated in contrast to the homogeneous Mongolian enrichment. In serial dilutions, growth was observed until $10^{-9}$ and it never resulted in pure cultures. Therefore, final isolation was performed on solid medium with acetonitrile. Purification on solid medium also took a very long time, since the fast-growing and numerically dominant colonies belonged to satellite heterotrophs unable to grow when transferred into liquid medium with acetonitrile. However, when after a month of incubation large yellow-orange colonies appeared, it became clear that they were responsible for the acetonitrile degradation. Their separation from the satellites took several cycles of transfer to liquid mediumplating. Eventually, two pure cultures, both yellowcoloured, were obtained, strain ANL 1 from the Kulunda lakes enrichment and strain ANL 6-2 ${ }^{\mathrm{T}}$ from the Mongolian lakes enrichment.

\section{Phenotypic and taxonomic characteristics}

In both isolates the cells were rod-shaped and of variable length, motile by a single polar or subpolar flagellum and with a typical Gram-negative cell wall structure and extended periplasm (Fig. 1). Strain ANL 1 formed aggregates during growth with acetonitrile. The biomass of both strains was yellow-orange. HPLC analysis of the crude pigment extract from strain ANL 6-2 ${ }^{\mathrm{T}}$ showed five carotenoid peaks. The major carotenoid was identified as $\left(3 R, 3^{\prime} R\right)$-zeaxanthin based on the retention time on HPLC, the absorption spectrum (Takaichi \& Shimada, 1992), the circular dichroism spectrum, the relative molecular mass of 564 and the ${ }^{1} \mathrm{H}-\mathrm{NMR}$ spectrum, which were compatible with those of authentic $\left(3 R, 3^{\prime} R\right)$-zeaxanthin. Four minor components were identified as adonixanthin, phenicoxanthin, $\beta$-cryptoxanthin and $\beta$-carotene based on the retention times on HPLC, the absorption spectrum and the relative molecular masses. The component ratio was $79 \%$ zeaxanthin, $9 \%$ adonixanthin, $4 \%$ phoenicoxanthin, $4 \% \beta$-cryptoxanthin and $4 \% \beta$-carotene. Fatty acid analysis of the membrane lipids showed a composition typical for moderately salt-tolerant bacteria with an absolute domination of $18: 1 \omega 7$ (66\% of total) and $16: 0$ as a secondary dominant ( $13 \%$ of total).

The $\mathrm{G}+\mathrm{C}$ content in the genomic DNA of ANL 1 and ANL $6-2^{\mathrm{T}}$ was 50.6 and $51.5 \mathrm{~mol} \%\left(T_{\mathrm{m}}\right)$, respectively. According to the DNA-DNA hybridization results, the two isolates might belong to separate gene species (DNA similarity level $55 \%)$. However, their phenotypic similarity and almost identical total protein profiles (data not shown) indicated that the new strains belong to the same species. Phylogenetic analysis based on $16 \mathrm{~S}$ rRNA gene sequencing placed the bacteria into the Gammaproteobacteria as a separate lineage within the family Ectothiorhodospiraceae (Fig. 2). The level of sequence homology between the strains was $98.7 \%$ and with the closest cultured relatives (AlkalilimnicolaAlkalispirillum group), $95 \%$.

\section{Growth characteristics of the pure cultures}

Both strains could grow with acetonitrile as sole source of carbon, energy and nitrogen. Ammonia accumulated in the medium but with different dynamics for the two strains. In strain ANL 6-2 ${ }^{\mathrm{T}}$ it was parallel to biomass growth, while in strain ANL 1 ammonia production was much faster but biomass yield was lower (Fig. 3a), indicating an imbalance between nitrile catabolism and biomass growth. The GC 

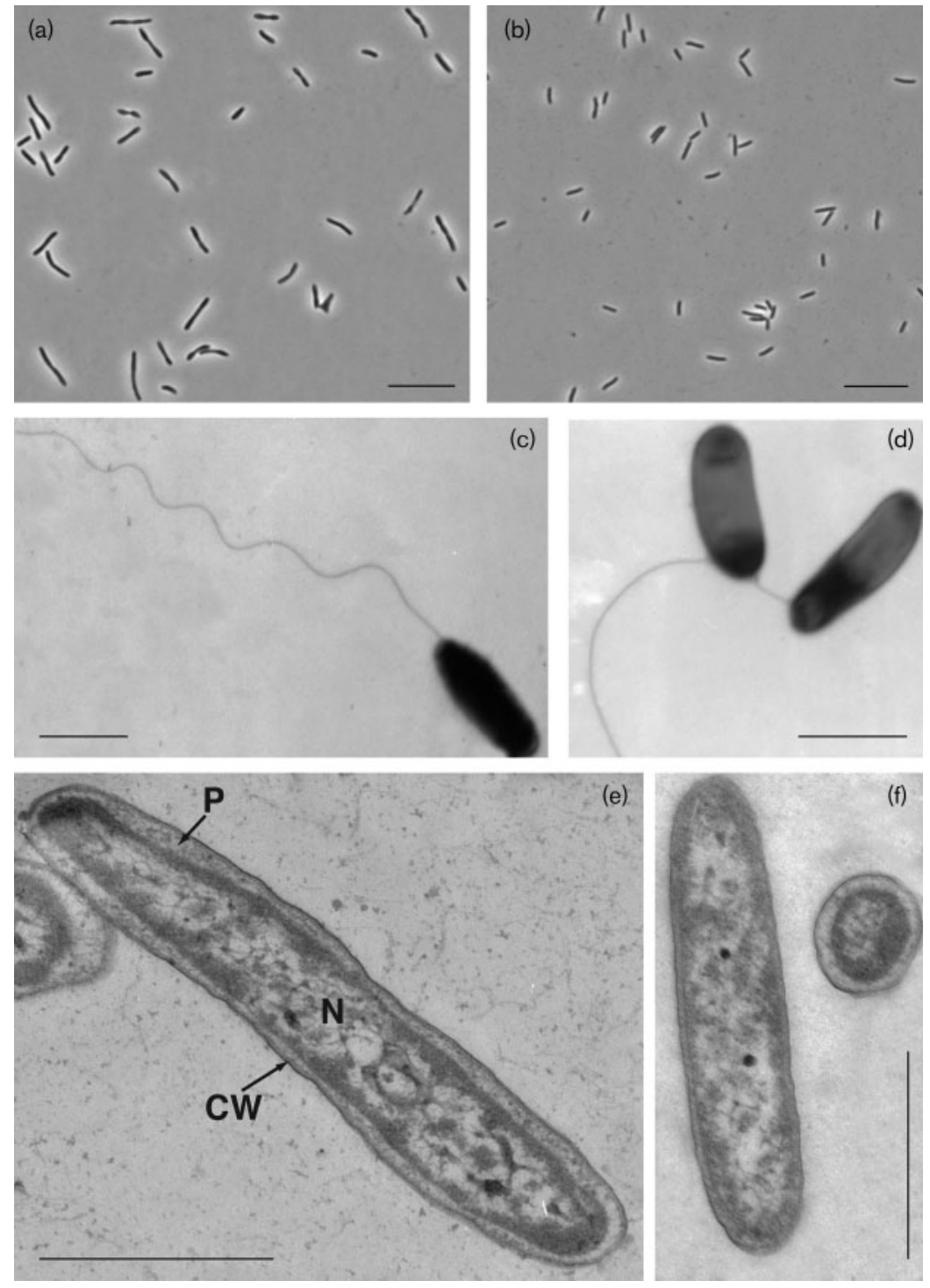

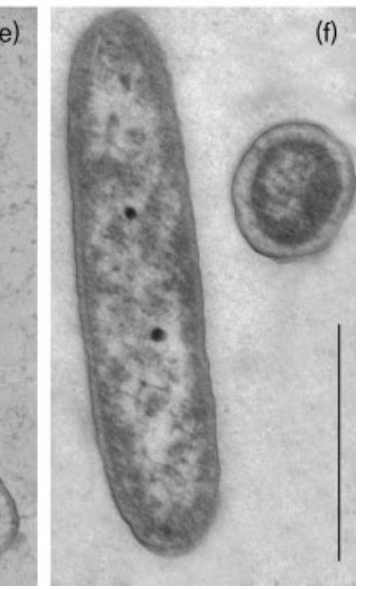

(d)

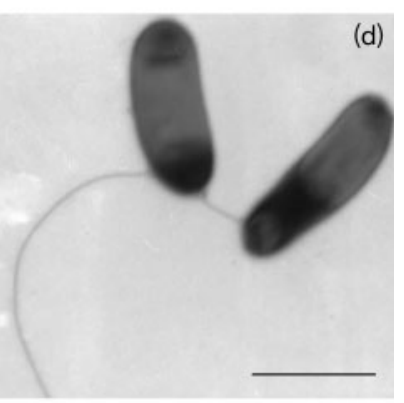

(1)

Fig. 1. Cell morphology of strains ANL 1 (a, $c, e)$ and ANL $6-2^{\top}(b, d, f)$ grown with acetonitrile at $\mathrm{pH}$ 10. (a, b) Phase-contrast; (c, d) electron micrographs, total preparations; $(e, f)$ electron micrographs, thin sections. Bars, (a, b) $10 \mu \mathrm{m},(\mathrm{c}-\mathrm{f}) 1 \mu \mathrm{m}$. CW, Cell wall; N, nucleoid; $\mathrm{P}$, periplasm. analysis of possible intermediates in the ANL $6-2^{\mathrm{T}}$ culture growing on acetonitrile was inefficient, i.e. neither acetamide nor acetic acid was found in the culture supernatant, probably due to a fast consumption and a low detection limit. However, GC analysis proved that acetonitrile consumption was parallel to biomass production (Fig. 3b). Maximal experimentally measured growth rates for strains ANL 1 and ANL 6-2 $2^{\mathrm{T}}$ with acetonitrile were 0.038 and $0.056 \mathrm{~h}^{-1}$, respectively. Growth with acetate and ammonium was approximately two times faster. From the other tested aliphatic nitriles (propio-, butyro-, isobutyro, valero- and acrylo-), only propionitrile could be used as sole substrate supporting growth with a maximum growth rate (ANL 6-2 ${ }^{\mathrm{T}}$ ) of $0.02 \mathrm{~h}^{-1}$. Ammonia was toxic to the bacteria (growing with acetate as substrate) with a $K_{\mathrm{i} 50}$ of $10 \mathrm{mM}$, thus it was a limiting and selective factor for alkaliphilic nitrile degradation, similar to what was found in the case of thiocyanate-utilizing alkaliphiles (Sorokin et al., 2001).
Limited potential to grow anaerobically with nitrate as the electron acceptor was observed in both strains either with acetate or acetonitrile as the electron donor. Nitrate was only reduced to nitrite, and growth was inhibited when the nitrite concentration reached $3 \mathrm{mM}$.

Both strains grew optimally with acetonitrile within an alkaline $\mathrm{pH}$ range, although there was a slight difference in optimal $\mathrm{pH}$ values (Fig. 4a). According to these data, the new isolates can be classified as obligate alkaliphiles. When inoculated from the medium containing $0.6 \mathrm{M}$ total $\mathrm{Na}^{+}$, $\mathrm{pH} 10$, both strains were able to grow with acetonitrile at sodium carbonate/bicarbonate concentrations up to $3.0 \mathrm{M}$ $\mathrm{Na}^{+}$with an optimum at $0.5 \mathrm{M}$ (Fig. 4b). Furthermore, after adaptation of the cultures at $3 \mathrm{M} \mathrm{Na}^{+}$, they also started to grow in saturated soda brines $\left(4 \mathrm{M}\right.$ total $\left.\mathrm{Na}^{+}\right)$, which qualified the new bacteria as extremely salt-tolerant natronophiles (Sorokin \& Kuenen, 2005). 


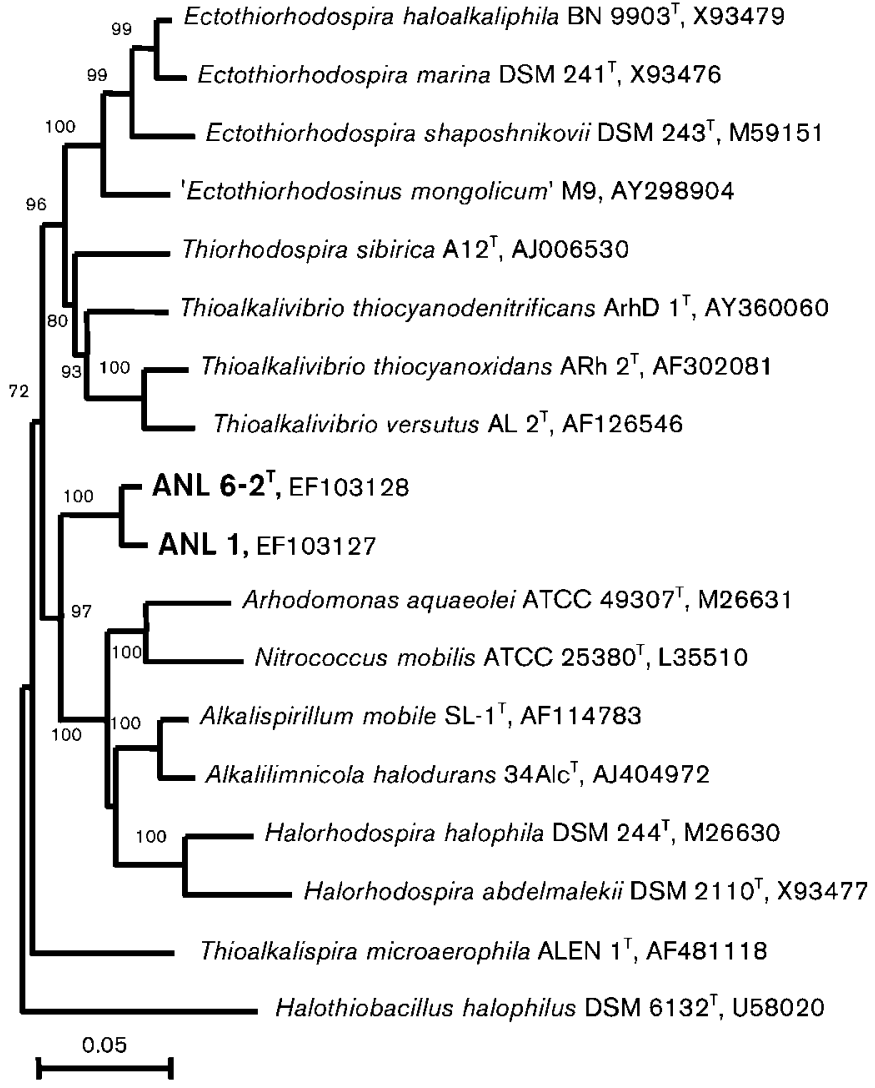

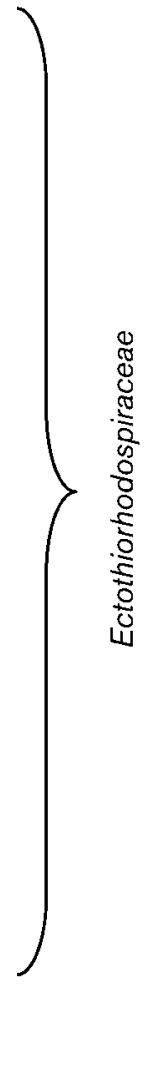

Fig. 2. Phylogenetic position of acetonitrileutilizing haloalkaliphilic bacteria from soda lakes within the family Ectothiorhodospiraceae, Gammaproteobacteria, based on 16S rRNA gene sequence analysis. Tree topography and evolutionary distances are given by the neighbour-joining method with Jukes \& Cantor distances. Numbers at the nodes indicate the percentage of bootstrap values for the clade in 1000 replications. Only values above $70 \%$ are shown.

\section{Metabolic activity of washed cells and in cell- free extract}

Washed cells of ANL strains, grown either with acetonitrile or propionitrile, produced ammonium from acetonitrile. When other substrates were used for growth, the specific activity of acetonitrile conversion dropped significantly, indicating the inducible nature of the nitrile-hydrolysing system in these organisms. Apart from acetonitrile and propionitrile, the nitrile-grown cells also had substantial activity with acrylonitrile and low activity with butyro-, isobutyro- and valeronitrile (Table 1). Cell disruption by sonication completely inactivated the nitrile-hydrolysing activity, but the acetamidase remained highly active [600-800 $\left.\mathrm{nmol}(\mathrm{mg} \text { protein })^{-1} \mathrm{~min}^{-1}\right]$. The latter indicates that (i) the alkaliphilic isolates use the nitrile hydratase/ amidase pathway, and (ii) nitrile hydratase activity limits the overall rate of nitrile hydrolysis. The nitrile hydratase/ amidase pathway was also evident from experiments with acrylonitrile, where the formation of acrylamide and acrylic acid from acrylonitrile by washed cells of strain ANL 6-2 was observed by HPLC analysis (data not shown).

A substantial difference was observed in the $\mathrm{pH}$ response between whole-cell acetonitrile hydrolysis and acetamidase activity in cell-free extract (Fig. 5). The amidase in strain ANL $6-2^{\mathrm{T}}$ is an apparently intracellular enzyme with a neutral $\mathrm{pH}$ optimum, while overall whole-cell acetonitrile hydrolysis remained active even at $\mathrm{pH}$ values above 11 .
Unfortunately, because of inactivation after cell disruption, no conclusion can be made about the $\mathrm{pH}$ preference of the nitrile hydratase in these alkaliphiles.

\section{DISCUSSION}

The results of this study have demonstrated for the first time the presence of nitrile-degrading potential in haloalkaliphilic bacteria living in soda lakes. The fact that these bacteria were able to grow with aceto- or propionitrile as sole substrates indicates that these simple aliphatic nitriles could be natural substrates in soda lake habitats, which are located far away from the industrial areas. Acetonitrile utilization as sole carbon, energy and nitrogen source has been shown for a few neutrophilic proteobacteria, such as Comamonas sp. (Betaproteobacterium; Manolov et al., 2005), Pseudomonas putida (Gammaproteobacterium; Chapatwala et al., 1993) and actinobacteria, such as Rhodococcus spp. (Blakey et al., 1995; Kohyama et al., 2006). All of them use the nitrile hydratase/amidase enzymic pathway.

One of the main interests in studying alkaliphilic nitrile degradation was to study the $\mathrm{pH}$ response of its nitriledegrading enzymes, i.e. whether they would exhibit tolerance of or even preference for high $\mathrm{pH}$ conditions. The results indicated that most probably, despite the high $\mathrm{pH}$ tolerance and its general alkaliphilic phenotype, enzymic nitrile hydrolysis in the soda lake isolates is at best 


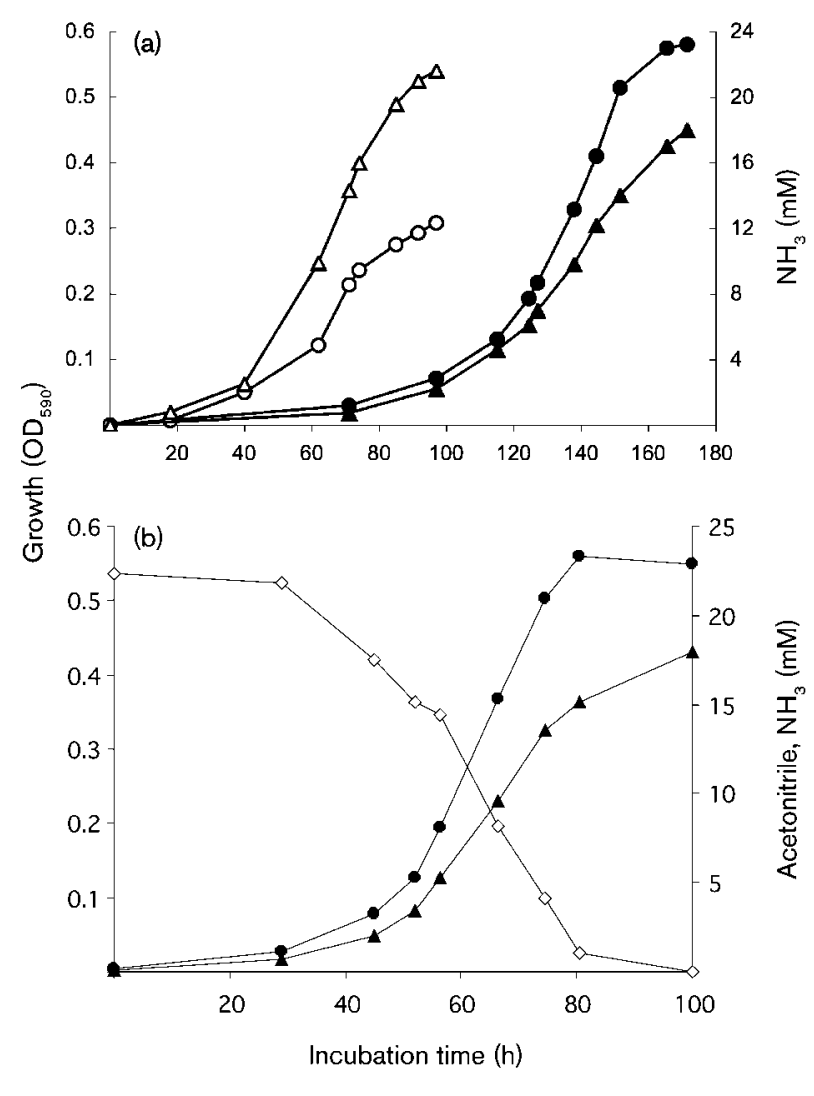

Fig. 3. Growth of alkaliphilic bacteria with acetonitrile at $\mathrm{pH}$ 10. (a) Comparison of growth dynamics of strains ANL 1 (open symbols) and ANL 6-2 ${ }^{\top}$ (closed symbols); (b) growth and acetonitrile consumption of strain ANL $6-2^{\mathrm{T}}$; circles, biomass; triangles, ammonia; diamonds, acetonitrile.

alkalitolerant. The latter is most probably a result of intracellular localization of the enzymes, as the cytoplasmic $\mathrm{pH}$ in alkaliphilic bacteria grown at an external $\mathrm{pH}$ of 10 stays around $\mathrm{pH} 8$. At least, this must be true for acetamidase, which was almost completely inactivated at $\mathrm{pH} 10-\mathrm{a} \mathrm{pH}$ value optimal for the growth of intact cells. Although such results are disappointing as far as our expectations of finding unusual nitrile-hydrolysing enzymes are concerned, on the other hand, whole-cell biocatalysis is still a major way of using nitrile-degrading micro-organisms in industry because of the unstable nature of nitrilehydrolysing enzymes. In this respect, the new alkaliphilic bacteria still have at least $2 \mathrm{pH}$ units ( $\mathrm{pH} 9-11)$ advantage over all known whole-cell nitrile-degraders.

Activity tests with whole cells and cell-free extract demonstrated that, similar to neutrophilic bacteria, the new alkaliphiles also use the nitrile hydratase/amidase pathway, but in this case the nitrile hydratase is the rate-limiting step. While the presence of the second enzyme (a nitrilase) cannot be completely excluded, it is not very likely, since the bacteria in this study could only degrade a few simple aliphatic nitriles, and nitrilases usually specialize on

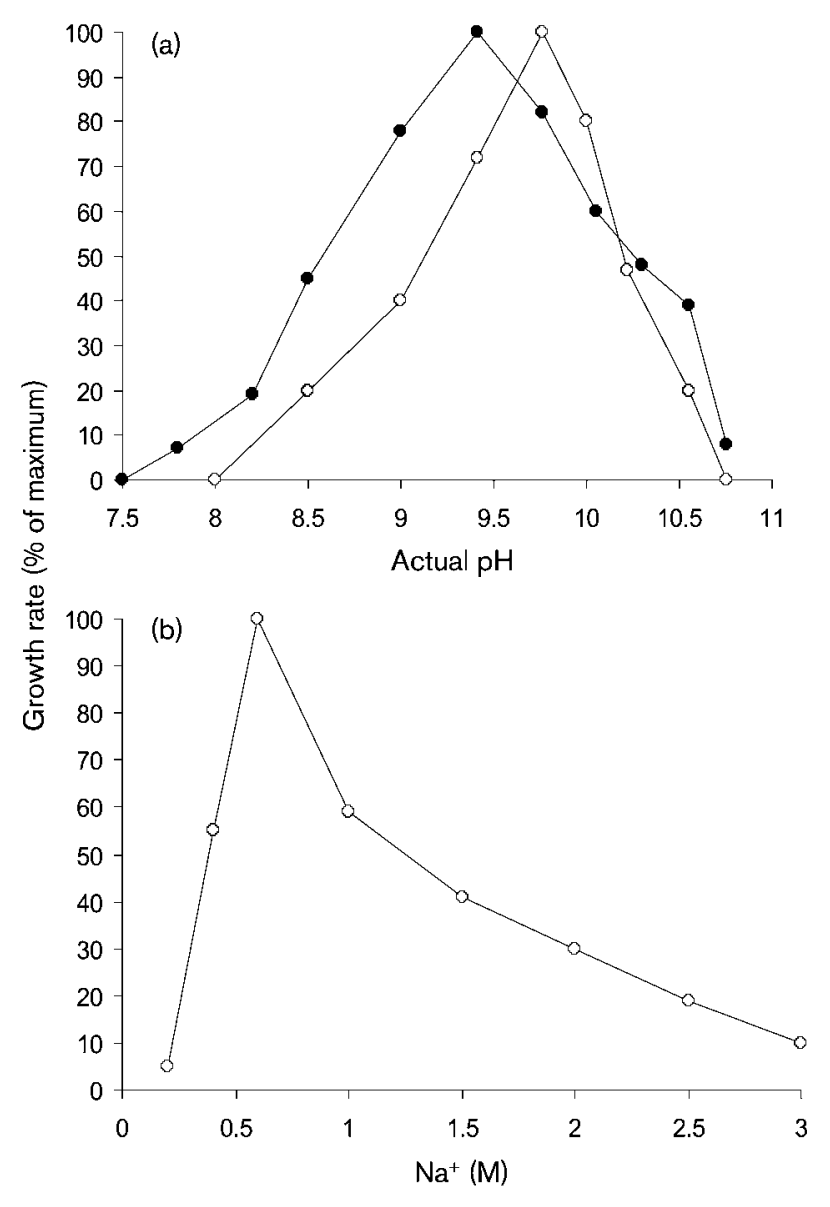

Fig. 4. Influence of $\mathrm{pH}$ at $0.6 \mathrm{M} \mathrm{Na}^{+}$(a) and sodium carbonate at $\mathrm{pH} 10$ (b) on growth of strains ANL 1 (open circles) and ANL $6-2^{\top}$ (closed circles) with acetonitrile. The following buffer systems were used: for $\mathrm{pH}$ range 7-8, $0.1 \mathrm{M} \mathrm{HEPES/}$ $0.6 \mathrm{M} \mathrm{NaCl} ; \quad \mathrm{pH} 8.2-8.5, \quad 0.5 \mathrm{M} \mathrm{NaHCO} / 0.1 \mathrm{M} \mathrm{NaCl}$; $\mathrm{pH} 9-11, \mathrm{NaHCO}_{3} / \mathrm{Na}_{2} \mathrm{CO}_{3} / \mathrm{NaCl}$.

aromatic or arylaliphatic nitriles (Banerjee et al., 2002). Furthermore, amidase activity in nitrilases, if present at all, is very low (Kobayashi et al., 2002). However, further specialized enzymological and molecular biological studies are required.

Phylogenetic analysis demonstrated that the new isolates belong to a previously unknown lineage within the family Ectothiorhodospiraceae, consisting mostly of phototrophic and lithotrophic (halo)alkaliphilic bacteria. The new bacteria, however, are obligate heterotrophs. Another difference is the presence of a high concentration of ketocarotenoids, which have not been found previously within the Ectothiorhodospiraceae (Takaichi, 1999). Based on the unique phenotype and separate phylogenetic position, these alkaliphilic acetonitrile-utilizing isolates are proposed to be accommodated into a new genus and species for which the name Natronocella acetinitrilica gen. nov., sp. nov. is proposed. 
Table 1. Substrate specificity of nitrile-hydrolysing system in washed cells of strain ANL 6-2 at $\mathrm{pH} 10$

1, Cells grown on acetonitrile; 2, cells grown on propionitrile; 3, cells, grown on acetate; 4, cells grown on yeast extract. ND, Not determined.

\begin{tabular}{|c|c|c|c|c|}
\hline \multirow[t]{2}{*}{ Substrate } & \multicolumn{4}{|c|}{ Activity of $\mathrm{NH}_{3}$ formation [ $\mathrm{nmol} \mathrm{min}{ }^{-1}(\mathrm{mg} \text { protein })^{-1}$ ] } \\
\hline & 1 & 2 & 3 & 4 \\
\hline Acetonitrile & 91 & 101 & 49 & 10 \\
\hline Propionitrile & 30 & 40 & $\mathrm{ND}$ & $\mathrm{ND}$ \\
\hline Acrylonitrile & 85 & 72 & - & - \\
\hline Butyronitrile & 12 & 12 & - & - \\
\hline Isobutyronitrile & 15 & 14 & - & - \\
\hline Valeronitrile & 12 & 11 & - & - \\
\hline Phenylacetonitrile & 13 & 4 & - & - \\
\hline $\mathrm{CN}^{-}, \mathrm{NCS}^{-}$ & 0 & 0 & - & - \\
\hline Acetamide & 680 & 610 & 220 & 40 \\
\hline Acrylamide & 270 & ND & $\mathrm{ND}$ & $\mathrm{ND}$ \\
\hline Isobutyroamide & 204 & - & - & - \\
\hline Formamide & 60 & - & - & - \\
\hline
\end{tabular}

\section{Description of Natronocella gen. nov.}

Natronocella (Na.tron.o.cel'la Gr. n. natron, soda; L. fem. n. cella, a cell; N.L. fem. n. Natronocella a cell that can tolerate soda)

Gram-negative bacteria with rod-shaped, yellow-pigmented

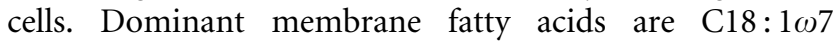
and C16:0. High-salt-tolerant and obligately alkaliphilic. Obligately heterotrophic. Can use aliphatic nitriles as

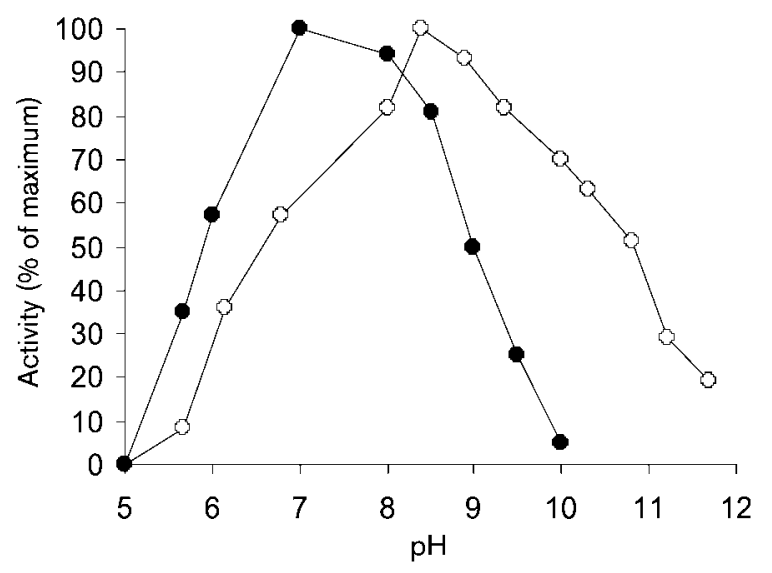

Fig. 5. Influence of $\mathrm{pH}$ on activity of acetonitrile conversion in strain ANL $6-2^{\top}$ grown with acetonitrile at $\mathrm{pH} 10$. Open circles, activity of ammonium formation from acetonitrile by washed cells $\left.\left[100 \%=120 \mathrm{nmol} \mathrm{NH}_{4}^{+} \text {(mg protein }\right)^{-1} \mathrm{~min}^{-1}\right]$; filled circles, acetamidase activity of cell-free extract $\left[100 \%=680 \mathrm{nmol} \mathrm{NH}_{4}^{+}\right.$ (mg protein) ${ }^{-1} \mathrm{~min}^{-1}$ ]. Buffers: $\mathrm{pH}$ range 5-8, $0.1 \mathrm{M} \mathrm{HEPES/}$ $0.6 \mathrm{M} \mathrm{NaCl}$; other buffers are as indicated in the legend to Fig. 2. carbon and energy source. Member of the family Ectothiorhodospiraceae, Gammaproteobacteria. Habitat is soda lakes. Type species is Natronocella acetinitrilica.

\section{Description of Natronocella acetinitrilica sp. nov.}

Natronocella acetinitrilica (ace.ti.ni.tri'li.ca N.L. adj. acetinitrilica pertaining to the ability to utilize acetonitrile)

Cells are rods, $1.5-4.0 \times 0.4-0.5 \mu \mathrm{m}$, motile with a single polar or subpolar flagellum. Yellow-coloured due to the presence of ketocarotenoids, dominated by zeaxanthin. Utilizes acetonitrile and propionitrile as carbon, energy and nitrogen source via nitrile hydratase/amidase enzyme system. Obligately alkaliphilic with a $\mathrm{pH}$ range for growth from 8 to 10.5 (optimum at 9.5-9.8). Can grow in saturated soda brines containing up to $4 \mathrm{M}$ total $\mathrm{Na}^{+}$(natronophile) with an optimum at $0.6 \mathrm{M} . \mathrm{G}+\mathrm{C}$ content of the DNA is $50.6-51.5 \mathrm{~mol} \%$. Includes two strains isolated from southwest Siberia (ANL 1=NCCB 100101=UNIQEM U235) and north-east Mongolia (ANL 6-2 $2^{\mathrm{T}}=\mathrm{NCCB} 100123^{\mathrm{T}}=$ UNIQEM U236 ${ }^{\mathrm{T}}$ ) soda lakes. Type strain is ANL 6-2 ${ }^{\mathrm{T}} .16 \mathrm{~S}$ rRNA gene sequences of strains ANL 1 and ANL 6-2 ${ }^{\mathrm{T}}$ have been deposited in GenBank under the accession numbers EF103127 and EF103128, respectively.

\section{ACKNOWLEDGEMENTS}

This work was supported by NWO-RFBR grant (047.011.2004.010), RFBR (grant 07-04-00153) and by the Program on Molecular and Cell Biology RAS. We are grateful to G. A. Osipov for the analysis of cellular fatty acid composition and to T. Maoka for the carotenoid analysis. 


\section{REFERENCES}

Almatawah, C. A., Cramp, R. \& Cowach, D. A. (1999). Characterisation of an inducible nitrilase from a thermophilic bacillus. Extremophiles 3, 283-291.

Banerjee, A., Sharma, R. \& Banerjee, U. C. (2002). The nitriledegrading enzymes: current status and future prospects. Appl Microbiol Biotechnol 60, 33-44.

Blakey, A. J., Colby, J., Williams, E. \& O'Reilly, C. (1995). Regio- and stereo-specific nitrile hydrolysis by the nitrile hydratase from Rhodococcus AJ270. FEMS Microbiol Lett 129, 57-62.

Bunch, A. W. (1998). Biotransformation of nitriles by rhodococci. Antonie van Leeuwenhoek 74, 89-97.

Chapatwala, K. D., Babu, G. R. V., Dudley, C., Williams, R. \& Aremu, K. (1993). Degradative capability of Pseudomonas putida on acetonitrile. Appl Biochem Biotechnol 39, 655-666.

De Ley, J., Caffon, H. \& Reinaerts, A. (1970). The quantitative measurements of hybridisation DNA from renaturation rates. Eur J Biochem 12, 133-140.

Gries-Romijn-van Eck (1966). Physiological and chemical test for drinking water. NEN 1056, IY-2 Nederlandse Normalisatie Instituut Rijswijk.

Håkansson, K., Welander, U. \& Mattiasson, B. (2005). Degradation of acetonitrile through a sequence of microbial reactors. Water Res 39, 648-654.

Harper, D. B. \& Gibbs, P. A. (1979). Identification of isobutyronitrile and isobutyraldoxime $O$-methyl ether as volatile microbial catabolites of valine. Biochem J 182, 609-611.

Jones, B. E., Grant, W. D., Duckworth, A. W. \& Owenson, G. G. (1998). Microbial diversity of soda lakes. Extremophiles 2, 191-200.

Kobayashi, M. \& Shimizu, S. (1998). Metalloenzyme nitrile hydratase: structure, regulation and application to biotechnology. Nat Biotechnol 16, 733-736.

Kobayashi, M. \& Shimizu, S. (2000). Nitrile hydrolases. Curr Opin Chem Biol 4, 95-102.

Kobayashi, M., Goda, M. \& Shimizu, S. (2002). Nitrilase catalyzes amide hydrolysis as well as nitrile hydrolysis. Biochem Biophys Res Commun 253, 662-666.

Kohyama, I., Yoshimura, A., Aoshima, D., Yoshida, T., Kawamoto, H. \& Nagasawa, T. (2006). Convenient treatment of acetonitrile-containing wastes using the tandem combination of nitrile hydratase and amidaseproducing microorganisms. Appl Microbiol Biotechnol 72, 600-606.

Layh, N., Hirrlinger, B., Stolz, A. \& Knackmuss, H.-J. (1997). Enrichment strategies for nitrile-hydrolysing bacteria. Appl Microbiol Biotechnol 47, 668-674.
Luque-Almagro, V. M., Huertas, M.-J., Martınez-Luque, M., MorenoVivian, C., Roldan, M. D., García-Gil, L. J., Castillo, F. \& Blasco, R. (2005). Bacterial degradation of cyanide and its metal complexes under alkaline conditions. Appl Environ Microbiol 71, 940-947.

Manolov, T., Håkansson, K. \& Benoit, G. (2005). Continuous acetonitrile degradation in a packed-bed bioreactor. Appl Microbiol Biotechnol 66, 567-574.

Marmur, J. (1961). A procedure for isolation of DNA from microorganisms. J Mol Biol 3, 208-214.

Pfennig, N. \& Lippert, K. D. (1966). Über das Vitamin $B_{12}$-bedürfnis phototropher Schwefelbacterien. Arch Microbiol 55, 245-256.

Podar, M., Eads, J. R. \& Richardson, T. H. (2006). Evolution of a microbial nitrilase gene family: a comparative and environmental genomics study. BMC Evol Biol 5, 42.

Sorokin, D. Yu. (2005). Is there a limit for high-pH growth? Int J Syst Evol Microbiol 55, 1405-1406.

Sorokin, D. Y. \& Kuenen, J. G. (2005). Alkaliphilic chemolithotrophs from sodas lakes. FEMS Microbiol Ecol 52, 287-295.

Sorokin, D. Yu., Tourova, T. P., Lysenko, A. M. \& Kuenen, J. G. (2001). Microbial thiocyanate utilization under highly alkaline conditions. Appl Environ Microbiol 67, 528-538.

Takaichi, S. (1999). Carotenoids and carotenogenesis in anoxygenic photosynthetic bacteria. In The Photochemistry of Carotenoids, pp. 39-69. Edited by H. A. Frank, A. J. Young, G. Britton \& R. J. Cogdell. Dordrecht: Kluwer.

Takaichi, S. \& Shimada, K. (1992). Characterization of carotenoids in photosynthetic bacteria. Methods Enzymol 23, 374-385.

Van de Peer, Y. \& De Wachter, R. (1994). TREECON for Windows: a software package for the construction and drawing of evolutionary trees for the Microsoft Windows environment. Comput Appl Biosci 10, 569-570.

Vetter, J. (2000). Plant cyanogenic glycosides. Toxicon 38, 11-36.

Weatherburn, M. V. (1967). Phenol-hypochlorite reaction for determination of ammonia. Anal Chem 39, 971-974.

Zavarzin, G. A., Zhilina, T. N. \& Kevbrin, V. V. (1999). The alkaliphilic microbial community and its functional diversity. Mikrobiologiia 68, 503-521.

Zhilina, T. N., Zavarzin, G. A., Rainey, F. A., Pikuta, E. N., Osipov, G. A. \& Kostrikina, N. A. (1997). Desulfonatronovibrio hydrogenovorans gen. nov., sp. nov., an alkaliphilic, sulfate-reducing bacterium. Int J Syst Bacteriol 47, 144-149.

Edited by: H.-P. Klenk 